\title{
Effects of Aquaculture Researchers'Job Characteristics on Linkage Activities in Nigeria
}

\author{
J.B Ogunremi ${ }^{1 *}$, E.O Faturoti ${ }^{2}$ and 0. Oladele $^{3}$
}

${ }^{1}$ Department of Biological Sciences, Ondo State University of Science and Technology, Okitipupa, Nigeria

${ }^{2}$ Department of Wildlife and Fisheries Management, University of Ibadan, Nigeria

${ }^{3}$ Department of Agricultural Economics and Extension, North West University Mafikeng Campus Mmabatho 2735, South Africa

\begin{abstract}
The study examined the effects of researchers' job characteristics on linkage activities in Nigeria due to the fact that many fish farmers have not been properly reached with technologies and the problem of poor food production has been attributed to the weak linkages existing between research, extension and fish farmers. A simple random sampling technique was used to select aquaculture researchers and their responses on involvement in linkage activities and level of job characteristics were elicited through a questionnaire. The result showed that researchers were satisfied with qualification for job (mean $=4.50$ ), opportunities to advance education and publish research (mean $=4.02$ and 4.0). No significant relationship exist between linkage and researchers job characteristics $(p<0.05)$. The paper concludes with the need to look into factors that will improve on the job characteristics and staff retention in the institute.
\end{abstract}

Keywords: Researchers; Aquaculture; Job satisfaction; Fish farmer; Linkage

\section{Introduction}

In Nigeria, the last two decades have witnessed food insecurity, a problem that has been significantly linked with low levels of technology widely applied in food production by majority of fish farmers. In order for productivity to increase accordingly and resulting industrial growth, more of that productivity will have to result from new knowledge and technology generated by agricultural research. Aquaculture research addresses two sets of problem: those related to the competitiveness of aquaculture products in domestic and global markets, and those related to the quality and maintenance of natural resources.

Advances made through agricultural research is an important factor in yield increase, this has also been identified as a major factor in increased food production [1]. Thus, research remains an important tool for a virile agricultural development programme in both developed and developing areas of the world. While aquaculture research has generated a lot of technologies adopted by farmers, its capacity to meet future challenges' is below what is actually required. Ogunremi [2] reported that the impact of agricultural research in generating research findings influences the effective performance of the agricultural sector. Aquaculture technology generation in Nigeria lies with University based and non-Univerist based scientists. There is a relatively long history of aquaculture researcher in Nigeria dating to as far back as 1975 [3]. Despite this, coupled with enormous investments in human and physical resources, the earlier anticipated result has not been fully realized. This connotes therefore, that the present performance in aquaculture leaves room for improvement. National Institute for Freshwater Fisheries Research (NIFFR) formerly known as Kainji Lake Research Institute was established in 1975 with national mandate for research on areas of fresh water fishes. The concept of linkage implies the communication and working relationship established between two or more organizations pursuing commonly shared objectives in order to have regular contact and improved productivity [4]

Salami [5] defined job satisfaction as the favorableness or un-favorableness with which employees view their works. It expresses the amount of agreement between ones' expectations of the job and the rewards that the job provides and therefore it relates to equity and mo- tivation theories. A person who is satisfied with his or her work will be committed to the organization and is more likely to contribute to high morale than people who are dissatisfied. Consequences of the employees' dissatisfaction are reflected in low labor turn over, frequent complaints, threats to down tools, excessive absenteeism from work, rumor mongering, and employees' generated petitions against the management, strikes and deterioration in employees' job performance [6]

The main objective of the study is to examine the effects of aquaculture researchers' job satisfaction on linkage activities in Nigeria.

The specific objectives are to:

(a) Identify linkage activities of aquaculture researchers.

(b) Determine satisfaction of aquaculture researchers with job characteristics.

\section{Hypothesis of the Study}

There is no significant relationship between linkage activities of aquaculture researchers and job characteristics.

\section{Methodology}

The study was carried out among aquaculture researchers from Nigeria Institute of Freshwater Fisheries Research (NIFFR) whose mandate is to carry out research on fresh water fisheries. Forty researchers were randomly selected from a total of 57 researchers in the Institute which represents $75 \%$ of the total population. A structured question-

*Corresponding author: JB Ogunremi, Department of Biological Sciences Ondo State University of Science and Technology, Okitipupa, Nigeria, E-mail: jogunremi@gmail.com

Received February 29, 2012; Accepted March 23, 2012; Published March 28 2012

Citation: Ogunremi JB, Faturoti EO, Oladele Ol (2012) Effects of Aquaculture Researchers' Job Characteristics on Linkage Activities in Nigeria. J Aquac Res Development 3:124 doi:10.4172/2155-9546.1000124

Copyright: (C) 2012 Ogunremi JB, et al. This is an open-access article distributed under the terms of the Creative Commons Attribution License, which permits unrestricted use, distribution, and reproduction in any medium, provided the original author and source are credited. 
Citation: Ogunremi JB, Faturoti EO, Oladele OI (2012) Effects of Aquaculture Researchers' Job Characteristics on Linkage Activities in Nigeria. J Aquac Res Development 3:124 doi:10.4172/2155-9546.1000124

Page 2 of 3

naire was administered on the researchers in the Fisheries research institute.

\section{Measurement of variables}

The dependent variables are linkage activities and independent variables are job characteristics. Twenty-four (24) of the linkage activities that researchers perform in the research institute were listed [7]. Researchers were to indicate if they performed these activities (Yes/No). Researchers indicated their degree of job satisfaction or dissatisfaction and its related characteristics were measured on a 5-point scale of not satisfied (NS), least satisfied (LS), fairly satisfied (FS), almost satisfied (AS) and most satisfied (MS) for fourteen job characteristics related statements. The tools used in analyzing data in this study were descrip- tive and inferential statistics. The former includes frequency counts and percentages while the later include correlation analysis.

\section{Results and Discussion}

The result of this study, (Table 1) shows that dissemination of knowledge and information (77.5\%); joint seminar and workshop training $(72.5 \%)$ and collaborative professional activities (70.0\%) are major linkage activities of researchers. These activities buttress the primary role of researchers in boosting farmers' productivity. Joint committees (20.0\%); joint financial resources $(27.5 \%)$ and joint field days $(35.5 \%)$ were not popular as linkage activities. Limited resources could be limiting where comprehensive and cooperating links have been established [8].

\begin{tabular}{|c|c|c|c|c|}
\hline & LINKAGE TYPES AND FUNCTIONS & YES & NO & TOTAL \\
\hline 1. & Joint problem identification & $22(55.0)$ & $18(45.5)$ & $40(100)$ \\
\hline 2. & Joint priority setting and planning & $18(45.0)$ & $22(55.5)$ & $40(100)$ \\
\hline 3. & Joint programming & $19(47.5)$ & $21(52.5)$ & $40(100)$ \\
\hline 4. & Joint technology publications & $23(57.5)$ & $17(42.5)$ & $40(100)$ \\
\hline 5. & Committees & $8 \quad(20.0)$ & $32(80.0)$ & $40(100)$ \\
\hline 6. & Collaborative professional activities & $28(70.0)$ & $12(30.0)$ & $40(100)$ \\
\hline 7. & Joint research contracts & $17(42.5)$ & $23(57.5)$ & $40(100)$ \\
\hline 8. & Joint research activities & $25(62.5)$ & $15(37.5)$ & $40(100)$ \\
\hline 9. & Exchanges of resources & $20(50.0)$ & $20(50.0)$ & $40(100)$ \\
\hline 10. & Joint facilitates (library, Laboratory) & $15(37.5)$ & $25(62.5)$ & $40(100)$ \\
\hline 11. & Joint financial resources & $11(27.5)$ & $29(72.5)$ & $40(100)$ \\
\hline 12. & Contact for services & $22(55.0)$ & $18(55.0)$ & $40(100)$ \\
\hline 13. & Staff rotation & $8(20.0)$ & $22(80.0)$ & $40(100)$ \\
\hline 14. & Dissemination of knowledge and information & $31(77.5)$ & $9(22.5)$ & $40(100)$ \\
\hline 15. & Joint publications & $28(70.0)$ & $12(30.0)$ & $40(100)$ \\
\hline 16. & Joint reports & $23(57.5)$ & $17(42.5)$ & $40(100)$ \\
\hline 17. & Joint demonstration trials & $19(47.5)$ & $21(52.5)$ & $40(100)$ \\
\hline 18. & Joint field days & $14(35.0)$ & $26(65.5)$ & $40(100)$ \\
\hline 19. & Joint audio - visual materials & $15(37.5)$ & $25(62.5)$ & $40(100)$ \\
\hline 20. & Joint seminar and workshop training & $29(72.5)$ & $11(27.5)$ & $40(100)$ \\
\hline 21. & Cross research - extension training & $23(57.5)$ & $17(42.5)$ & $40(100)$ \\
\hline 22. & Evaluation survey & $21(52.5)$ & $19(47.5)$ & $40(100)$ \\
\hline 23. & Evaluation field visits & $16(40.0)$ & $24(60.0)$ & $40(100)$ \\
\hline 24. & Evaluation reports & $20(50.0)$ & $20(50.0)$ & $40(100)$ \\
\hline
\end{tabular}

Note: Figures in parentheses are percentages

Table 1: Linkage activities among researchers.

\begin{tabular}{|c|c|c|c|c|c|c|c|c|c|c|c|c|c|}
\hline S.No & JOB CHARACTERISTICS & NS & Freq. \% & LS & Freq. \% & FS & Freq. \% & AS & Freq. \% & MS & Freq. \% & Mean & SD \\
\hline 1. & Qualification for job & - & - & 2 & 5.0 & 3 & 7.5 & 8 & 20.0 & 27 & 67.5 & 4.50 & 0.85 \\
\hline 2. & In - Service training & 2 & 5.0 & 6 & 15.0 & 10 & 25.0 & 10 & 25.0 & 12 & 30.0 & 3.60 & 1.22 \\
\hline 3. & Word exposure & 8 & 20.0 & 8 & 20.0 & 6 & 15.0 & 8 & 20.0 & 10 & 25.0 & 3.60 & 1.50 \\
\hline 4. & Research policies & 7 & 17.5 & 8 & 20.0 & 7 & 17.5 & 13 & 32.5 & 5 & 12.5 & 3.03 & 1.33 \\
\hline 5. & Identification farmers' problems & 5 & 12.5 & 11 & 27.5 & 13 & 32.5 & 7 & 17.5 & 4 & 10.0 & 2.85 & 1.17 \\
\hline 6. & Job security & 2 & 5.0 & 13 & 32.5 & 8 & 20.0 & 11 & 27.5 & 16 & 40.0 & 3.90 & 1.17 \\
\hline 7. & Transportation & 14 & 35.0 & 12 & 30.0 & 8 & 20.0 & 4 & 10.0 & 2 & 5.0 & 2.20 & 1.18 \\
\hline 8. & Availability of experimental land & 8 & 20.0 & 5 & 12.5 & 8 & 20.0 & 10 & 25.0 & 9 & 22.5 & 3.17 & 1.45 \\
\hline 9. & Work equipment and tools & 13 & 32.5 & 8 & 20.0 & 11 & 27.5 & 5 & 12.5 & 3 & 7.5 & 2.43 & 1.28 \\
\hline 10. & Opportunities to advance education & - & - & 3 & 7.5 & 6 & 15.0 & 18 & 45.0 & 13 & 32.5 & 4.02 & 0.89 \\
\hline 11. & Opportunities to publish research & - & - & 5 & 12.5 & 3 & 7.5 & 15 & 37.5 & 17 & 42.5 & 4 & 1.01 \\
\hline 12. & Rewarding system & 11 & 27.5 & 14 & 35.0 & 9 & 22.5 & 4 & 10.0 & 2 & 5.0 & 2.30 & 1.14 \\
\hline 13. & $\begin{array}{l}\text { Relationship among professionals } \\
\text { and administrative staff }\end{array}$ & 8 & 20.0 & 7 & 17.5 & 15 & 37.5 & 7 & 17.5 & 3 & 7.5 & 2.75 & 1.19 \\
\hline 14. & Budgeting & 10 & 25.0 & 7 & 17.5 & 7 & 17.5 & 11 & 27.5 & 5 & 12.5 & 2.85 & 1.41 \\
\hline
\end{tabular}

Table 2: Researchers level of satisfaction with job characteristics NS= Not satisfied, LS= Least satisfied, FS=fairly satisfied, AS= Almost satisfied, MS=Mostly satisfied. 
Citation: Ogunremi JB, Faturoti EO, Oladele OI (2012) Effects of Aquaculture Researchers' Job Characteristics on Linkage Activities in Nigeria. J Aquac Res Development 3:124 doi:10.4172/2155-9546.1000124

Page 3 of 3

\begin{tabular}{|llcllll|}
\hline Variables & Mean & Std.Deviation & $\mathrm{r}$ & $\mathrm{p}$ & $\mathrm{df}$ & Remark \\
\hline Linkage & 42.4000 & 8.4088 & & & & \\
\hline $\begin{array}{l}\text { Job characteristics } \\
\text { significant }\end{array}$ & 126.7500 & 29.6005 & -.237 & .141 & 40 & Not \\
\hline
\end{tabular}

Table 3: Pearson correlation between linkage and researchers job characteristics. $(n=40)$

The analysis in Table 2 attempts to determine researchers' level of satisfaction regarding various job characteristics in the discharge of their duties which is linkage. The results show that researchers satisfaction in job characteristics include qualification for job (mean $=4.50)$, opportunities to advance education and publish research (mean of 4.02 and 4.0). However, transportation and rewarding system (mean 2.20 and 2.30) are other job characteristics that were unsatisfactory to the researchers.

Analysis was conducted to determine if significant relationship exist between linkage and researchers job characteristics (Table 3 ). The result of the analysis indicates that there is no significant relationship between linkage and researchers job characteristics.

\section{Conclusion}

The study indicates that dissemination of knowledge and information; joint seminar and workshop training and collaborative professional activities are major linkage activities of researchers. The findings of the study also revealed high qualification for job, opportunities to advance education and publish research to be the most satisfied job characteristic among the researchers. No correlation exists between linkage and researchers job characteristics. The most valuable resource of an agricultural research organization is its people; there is therefore the

need to create conducive working conditions, increased participation and involvement, a good reward system and the work itself.

\section{References}

1. Erinle E (1994) The Need for an Effective Agricultural Research Programme In B Shaub, NO Adedipe, OA Odegboro, AAliyu (Eds). Towards Strengthening the Nigeria Agricultural Research System. NARP publication. University of Ibadan press, Ibadan, Nigeria 152

2. Ogunremi JB, Olaniran TS (2010) A Comparative Analysis of Scientist Linkage Activities in University and Non-University based Aquaculture Research Institutes in Nigeria. Pakistan Journal of Agricultural Science 47: 259-261.

3. Yusuf SA, Omonona BT (2002) Agricultural research and poverty alleviation. In F. Okumadewa, (Ed.). Nigeria Poverty Reduction and Nigeria Agricultural Sector. Elshaddai Global Ventures Ltd. Mokola, Ibadan.pg .145-164.

4. Agbamu UJ (2000) Agricultural Research-Extension Linkage Systems: An International Perspective in Agricultural Research and Extension Network, AGREN Paper N0 106

5. Salami SO (2000) Work Values as Correlates of Job Satisfaction among Nigerian Nurses. African Journal of Cultural Psychology and Sports Facilitation 2: $46-51$.

6. Apooyin A (2009) Job Satisfaction, Career-Commitment, Self-esteem and Selfefficiency as Correlates of Job Performance among Coaches in South-Western Nigeria. Unpublished Ph.D Thesis in the Department of Human Kinetics and Health Education University of Ibadan, Ibadan.141.

7. Oladele OI (1997) Analysis of the institutional Research-Extension-farmers linkage system in south-western Nigeria. Unpublished Ph.D Thesis in the Department of Agricultural Extension and Rural Development, University of Ibadan, Ibadan.141.

8. Oladele OI, Sakagami J, Toriyama K (2006) Research-extension-farmer linkage system in Southwestern Nigeria. Journal of Food Agriculture and Environment 4: 197-200. 